\title{
Cloning, Expression, and Immunogenicity Analysis of the CpsE Protein from Group B Streptococcus Isolated from Tilapia (Oreochromis Niloticus)
}

\author{
$\mathrm{Xi} \mathrm{Fu}^{1}$, Kaiyu Wang ${ }^{1}$, Jinlu Huang ${ }^{1}$, Jun Wang ${ }^{1}$, Hai Lian ${ }^{1}$, Yang $\mathrm{He}^{1}$, Lanmin $\mathrm{Li}^{1}$, Kaiyu Wang ${ }^{2}$ \\ ${ }^{1}$ Fish Disease Research Center, College of Veterinary Medicine of Sichuan Agricultural University, Ya’an,China \\ ${ }^{2}$ Key Laboratory of Animal Disease and Human Health of Sichuan Province, \\ College of Veterinary Medicine of Sichuan Agricultural University, Ya’an, China \\ Email: kywangsicau@126.com
}

Received 2012

\begin{abstract}
Group B Streptococcus (GBS) is a major cause of serious bacterial infection in numerous animal species. The production of capsular polysaccharide(CPs) is vital to GBS to evade host immunity. One of the genes that required for production of CPs, cpsE, has been determined to be well conserved in capsule gene cluster (cps). This study cloned the cpsE gene from Tilapia of GBS clinical isolate (serotype Ia) and expressed this gene with aid of pET-32a(+) in Escherichia coli BL21(DE3) competent cells to obtain high levels of the recombinant protein for further study about CpsE in fish and examination of its immunogenicity. The optimization of induction conditions (IPTG concentration, temperature and time) in E.coli was accomplished and let us to perform the recombinant protein induction at $37^{\circ} \mathrm{C}$ for 3h,with $0.2 \mathrm{mM}$ IPTG in Luria Bertani (LB) medium. At the optimal conditions, recombinant protein was expressed in an insoluble form (inclusion bodies) and accounted for approximately $23 \%$ of the total protein. Purification by affinity chromatography yielded about 480mg fusion protein per liter culture.
\end{abstract}

Keywords: Recombinant CpsE Expression; Purification; Polyclonal Antibody

\section{Introduction}

Group B Streptococcus (GBS) is the foremost cause of life-threatening bacterial infection in human and other animals [1-4]. GBS also causes septicaemia and meningitis of obvious morbidity and mortality in fish such as tilapia (Oreochromis niloticus), cultured seabream, and wild mullet [5-7]. It is commonly believed that the threat of GBS disease is a considerable health burden for society.

For GBS, CPs is a major virulence factor as well as a target for protective immunity [8].To date, ten serotypes (serotypes Ia, Ib, and II through IX) of GBS have been identified based on their unique $\mathrm{CP}_{\mathrm{S}}$ antigens[10-12]. Among these serotypes, Ia、 III V and VIII are prevalent among human [11,13,14], the most currently isolated from fish are Ia , Ib and III $[15,16]$.

There are five genes ( $c p s A$ to $-E$ ) that are well conserved among several polysaccharide-producing streptococci including S. thermophilus, S. pneumoniae, S. suis and among the GBS capsule serotypes[17-19]. According to Cieslewicz et al[20], inactivation of cpsIaE resulted in an acapsular phenotype, consistent with previous work that identified CpsE as the glycosyltransferase [18,22].

Impact of GBS infection on fish was sporadically reported throughout the world [5,6,23-25] . Here we report molecular cloning v prokaryotic expression and purification of the recombinant protein. Additionally, we studied the optimal induction conditions for recombinant protein including concentration of IPTG (Isopropyl b-D-1-thiogalactopyranoside), induction temperatures and induction time.

\section{Materials and Methods}

\subsection{Clinical Isolate, Plasmids and Culture Conditions}

GBS strains $(n=10)$ were isolated from liver、brain and kidney from 100 infected tilapia (Wen-chang City, Hainan Province ,China). One virulent strain was selected through regression test over healthy tilapia. The strain was identified to express the type Ia capsule by multiplex PCR assay [26]. All E.coli clones were routinely grown in LB broth containing $100 \mu \mathrm{g} / \mathrm{ml}$ of ampicillin at $37^{\circ} \mathrm{C}$.

\subsection{Translated Protein Analysis}

The Protean program of software DNAStar was used to predict the secondary structure and the surface probability as well as antigenic index of translated protein. SOSUI Server (http://bp. nuap.nagoya-u.ac.jp/sosui/sosui_submit.html) and SignalP 4.0 Server (http://www.cbs.dtu.dk/services/SignalP/) were used to analyze the presence of transmembrane regions and signal peptide, respectively. The hydrophilicity character of the protein sequence was predicted by software Bioedit7.0.Chance of insolubility of target protein over-expressed in E.coli was predicted using online program (http://www.biotech.ou.edu/).

\subsection{Primer Design and PCR Amplification of the cpsE Gene}

The full-length of cpsE gene in this study (GenBank accession no. 
tion sites Bam HI and Hind III (underlined), respectively. Primers: $\quad$ upstream $\quad 5^{\prime}$ CGGGATCCATGAAAATTTGTCTGGTTGG -3'
$\begin{aligned} & \text { downstream } \\ & 5^{\prime}\end{aligned}$
CCAAGCTTTTAAAAAATTCCTCCTAAATT-3').

Amplification was done at $94^{\circ} \mathrm{C}$ for $5 \mathrm{~min}$ and then at $94^{\circ} \mathrm{C}$ for $1 \mathrm{~min}, 55^{\circ} \mathrm{C}$ for $1 \mathrm{~min}$, and $72^{\circ} \mathrm{C}$ for $40 \mathrm{~s}$ for a total of 30 cycles, followed by $72^{\circ} \mathrm{C}$ for $10 \mathrm{~min}$.

\subsection{Construction of Cloning Plasmid and Expression Plasmids}

The target fragment was ligated into cloning vector pMD19-T to construct recombinant cloning plasmid pMD19-T/cpsE. Competent E.coli strain DH5 $\alpha$ cells were used for host cloning construction.

The pET-32a $(+)$ vector and the recombinant cloning plasmids were both digested with Bam $\mathrm{HI}$ and Hind III and were both spliced with T4 ligase (Takara, Japan) to construct the recombinant prokaryotic expression plasmid pET-32a(+)/cpsE. The ligated product was transformed into competent DH5a cells. Selection of positive clones was done by PCR amplification, double enzymes digestion and sequence analysis. The positive clones were transformed into expression hosts of BL21 (DE3) cells.

\subsection{Expression and Optimization of Expression Conditions}

Transformants were inoculated into $5 \mathrm{ml}$ of culture medium in test tubes and grown overnight at $37^{\circ} \mathrm{C}$ with constant agitation (220 rpm) until they reached the exponential phase (approximately $\mathrm{OD}_{600} \approx 0.5-0.6$ measured by absorbance at $600 \mathrm{~nm}$ ) and were subsequently induced with IPTG. Preliminary tests were performed with $1 \mathrm{mM}$ IPTG induction at $37^{\circ} \mathrm{C}$ for $4 \mathrm{~h}$ and for the optimization of mature CpsE expression. Optimization of the expression conditions were performed at different temperatures $\left(30^{\circ} \mathrm{C}, 34^{\circ} \mathrm{C}\right.$, and $37^{\circ} \mathrm{C}$ ), for different induction periods (1h, 2h, 3h, 4h, 5h, 6h, $7 \mathrm{~h}$ and overnight) and with different IPTG concentrations (0.2mM, 0.4mM. $0.6 \mathrm{mM}, 0.8 \mathrm{mM}, 1.0 \mathrm{mM}$, $1.2 \mathrm{mM}, 1.5 \mathrm{mM}$ and $2.0 \mathrm{mM})$.

\subsection{Purification of the His6-tagged Recombinant Protein}

The His6-tagged recombinant protein was subjected to Bio$\operatorname{Rad}^{\mathrm{TM}}$ metal affinity chromatography for purification. Under denatured state, CpsE-containing fractions were pooled and dialyzed against PBS buffer $\left(10 \mathrm{mM} \mathrm{Na}_{2} \mathrm{HPO}_{4} 1.8 \mathrm{mM} \mathrm{KH}{ }_{2}\right.$ $\mathrm{PO}_{4}, \mathrm{pH} 7.4,140 \mathrm{mM} \mathrm{NaCl}$, and $2.7 \mathrm{mM} \mathrm{KCl}$ ) with step-wise lower concentrations of urea $(6 \mathrm{M}, 4 \mathrm{M}, 2 \mathrm{M}$ and $0 \mathrm{M}$ ) for a total time of $96 \mathrm{~h}$. The purified recombinant protein was stored at $4^{\circ} \mathrm{C}$ for use within 1 week or at $-70^{\circ} \mathrm{C}$ for longer time.

\section{Results}

\subsection{GBS Strain Isolate Confirming}

Bacterial isolates from infected tilapia were initially identified as GBS by conventional phenotypic characteristics (Grampositive cocci, $\beta$-haemolytic, catalase negative, API 20 STREP system, Slidex Strepto-kit). Slidex Strepto-kit was positive for group B and API 20 STREP gave profile number 3663414, which corresponded to excellent matches to GBS.

\subsection{Bioinformatics Prediction}

The analysis results obtained by the software DNAStar indicated that there were nine distinct antigenic domains and six surface probability domains. This program also showed a measurable amount of beta strands with few turn regions and random coil. Prediction of SignalP 3.0 Server confirmed the absence of signal peptide in CpsE sequence. Program SOSUI Server indicated that amino acids from 80-102aa in the cpsE gene may be part of a transmembrane region in the CpsE protein sequence .Results indicate that this region (80-102aa) is likely anchored to the bacterial wall. And possibility of insolubility when over-expressed in E.coli was 64.1\%.

\subsection{Plasmids Construction}

Coning plasmid pMD19-t/cpsE was confirmed by double restriction enzymes digestion (Bam HI and Hind III) (Figure 1) and sequencing analysis. Correct fragment was fused with pET-32a (+) to form the expression plasmid pET-32a (+)/cpsE. The initial transformation was performed with competent DH5acells for screening. The positive clones were identified by PCR amplification and double restriction enzymes digestion (Figure 2).

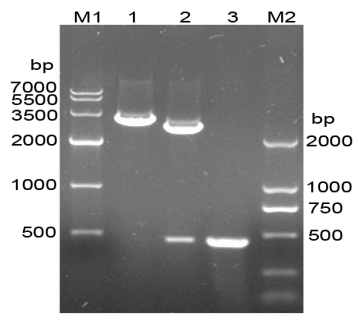

Figure1. Characterization of the recombinant plasmid pMD19T/cpsE by restriction digestion and PCR-based amplification.M1: DNA marker of 7000bp; lane 1:pMD19-T/cpsE digested with Bam HI; lane 2:pMD19-T/cpsE digested with Bam HI and Hind III; lane 3:PCR amplification product of cpsE (ORF450bp); M2:DNA marker of 2000bp

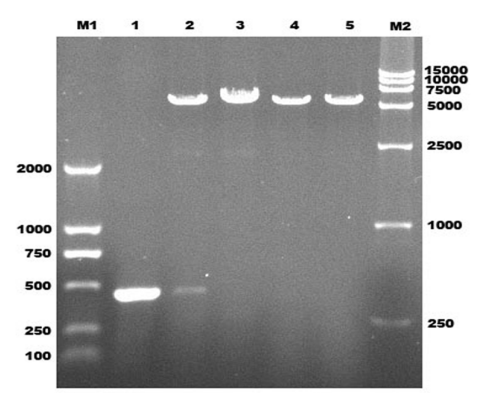

Figure 2. Characterization of the recombinant plasmid pET-32a(+)/cpsE by restriction digestion and PCR-based amplification. M1:DNA marker of 200bp;lane 1:PCR amplification product of cpsE; lane 2:pET-32a(+)/cpsE digested with Bam $\mathrm{HI}$ and Hind III; lane 3: pET-32a(+)/cpsE digested with Bam HI; lane 4: pET-32a(+)digested with Bam HI and Hind III; lane 5: pET-32a(+) digested with Bam $\mathrm{HI}$. 


\subsection{Expression of the Recombinant Protein}

The protein expression was observed in expression host BL21 (DE3). A distinct band of approximately $36 \mathrm{kDa}$ of molecular weight, which corresponded to the expected size of the His6tagged CpsE fusion protein, was observed (Figure 3a). Distinct or correct band was not detected in both un-induced sample and the pET-32a $(+)$ vector culture in BL21 (DE3) cells (Figure 3(a)).The target protein was mainly expressed in the insoluble fraction, in the form of inclusion bodies.

\subsection{Optimization of Culture Conditions}

We examined effects of the induction temperature, induction periods and IPTG concentration on the CpsE expression level. The expression level was analyzed by SDS-PAGE.The recombinant protein expression was best in BL21 (DE3) cells with $0.2 \mathrm{mM}$ IPTG induction (Figure $\mathbf{3 b}$ ) at $37^{\circ} \mathrm{C}$ (Figure $\mathbf{3 a}$ ) for $3 \mathrm{~h}$ (Figure 3c) after the culture reached an $\mathrm{OD}_{600}$ of 0.6. Therefore, this condition was used throughout the paper for the induction of CpsE expression.

\subsection{Purification and Immunogenicity Analysis of the Recombinant Protein}

The CpsE was mainly eluted from Ni-NTA column using 250mM imidazole (Data not shown). A clear band corresponded to a molecular mass of about $36 \mathrm{kDa}$ was observed on the SDS-PAGE gel staining with Coomassie brilliant blue
(Figure 4). From a 1-L culture, 1.62mg of purified CpsE was obtained. (4g of wet weight cell pellets were obtained from $1 \mathrm{~L}$ of bacterial culture in confirmed expression conditions in our study) The purification profile is summarized in Table 1.

\section{Discussion}

GBS is among a select number of significant human and animal pathogenic bacteria expressing polysaccharide. CPS confer virulence on these organisms by interfering with the mechanisms of host immune recognition[27].The striking conservation of $c p s E$ gene among GBS of different serotypes has suggested that the product of this gene has function that is independent of the repeating unit structure of the associated polysaccharide. To our knowledge, there are no reports on characterization of CpsE in fish.

Studies report that CpsE is expressed in heterologous expression systems in E.coli [18].In this work, cpsE from GBS namely serotype Ia, isolated from clinical tilapia, was cloned for expression at high levels in E.coli with the intention of detecting immunogenicity and further characterization of this protein in fish.

The result obtained for CpsE solubility indicated that the mature protein (without signal peptide), with the transmembrane region and a theoretic relative high possibility of insolubility when over-expressed in E.coli, is mainly retained in the insoluble fraction. This result corroborates the bioinformatics prediction that overall the recombinant protein presents a hydrophobic character.

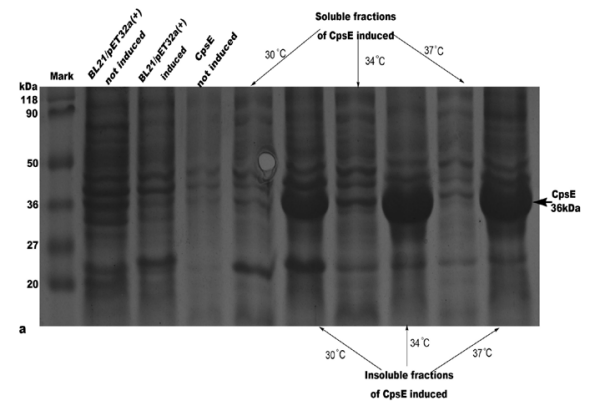

(a)

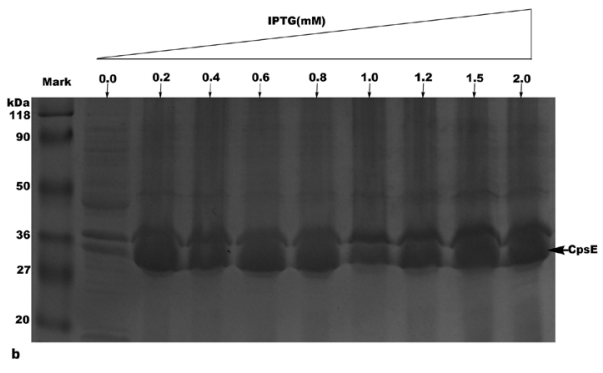

(b)

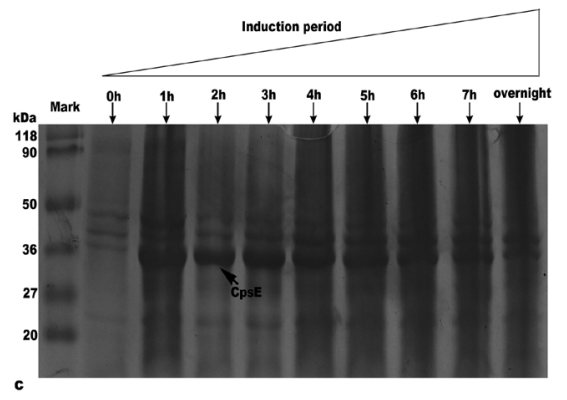

(c)

Figure 3. (a) His6-tagged CpsE expression in BL21(DE3) at different temperature conditions on a 12.5\%SDS-PAGE gel.The sample are diluted five folds relative to the standard preparation for the gel $(25 \mu \mathrm{l}$ of the sample buffer for each $1 \mathrm{~mL}$ of cell pellet at $\mathrm{Abs600}=0.6)$; $(\mathrm{b})$ SDS-PAGE analysis for optimization of the concentration of IPTG for His6-tagged CpsE expression; (c) His6-tagged CpsE expression for different induction period on a 12.5\%SDS-PAGE gel.It is able to compare the expression levels among lanes for an equal amount of sample was loaded into each lane. 


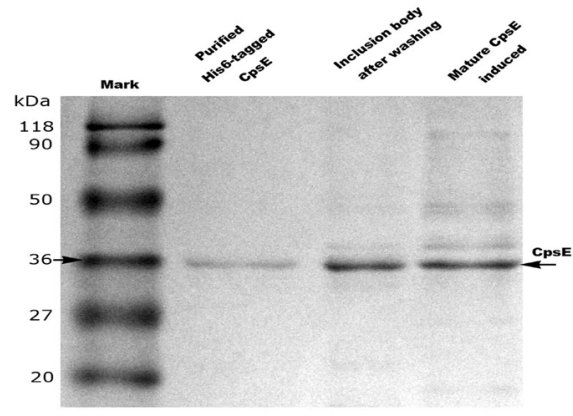

Figure 4. Purified CpsE on a $12.5 \%$ SDS-PAGE gel eluted from Ni-NTA column using $250 \mathrm{mM}$ imidazole. Expression of all lanes are accomplished at optimal conditions (at $37^{\circ} \mathrm{C}$ for $1 \mathrm{~h}$ with $0.2 \mathrm{mM}$ IPTG induction).

Table 1. Purification of cpse protein from 11 culture.

\begin{tabular}{lcccc}
\hline \multicolumn{1}{c}{ Step } & $\begin{array}{c}\text { Total } \\
\text { protein }^{\mathrm{a}} \\
(\mathrm{mg})\end{array}$ & $\begin{array}{c}\text { CpsE } \\
(\mathrm{mg})\end{array}$ & $\begin{array}{c}\text { Protein } \\
\text { concentration } \\
\mu \mathrm{g} / \mathrm{ml}^{\mathrm{b}}\end{array}$ & $\begin{array}{c}\text { Purity } \\
(\%)^{\mathrm{c}}\end{array}$ \\
\hline Crude extract $^{\mathrm{d}}$ & 67.5 & 15.48 & 1,214 & 23 \\
$\begin{array}{l}\text { Immobilized metal affinity } \\
\text { chromatography }\end{array}$ & 1.90 & 1.62 & 480 & 85 \\
\hline
\end{tabular}

${ }^{\mathrm{a}}$ Total protein was isolated from 1liter of culture medium in optimal expression condition; ${ }^{b}$ Protein concentration was estimated by the Bradford method using BSA as standard; ${ }^{\mathrm{c}}$ The purity was determined as the amount of the stain associated with the CpsE band as a fraction of the stain associated with all the bands on the SDS-PAGE[28]; ${ }^{\mathrm{d}}$ The pellets containing the insoluble fraction (crude extract) obtained from 1liter of culture.

To date, there are no reports in literature that approached the expression optimization allowing the development of a process to produce recombinant CpsE in E.coli. Our work is able to present conditions that are optimal for production of recombinant protein. Distribution of B cell epitopes is largely related to the secondary structures of the protein because regions of turn and coil can easily change in shape that benefits combination of protein with antibodies. Hydrophilic regions of the protein would serve as likely B cell epitopes. Prediction results of hydrophilicity character and transmembrane region indicate that there may have certain B cell epitopes in the CpsE protein. Comprehensive analysis of turn regions, coil regions, surface probability regions and hydrophilic regions presented here suggest that the most possible sites for B cell epitopes are Phe52-Asn57, Gly7-Gly11, Ser83-Gly84 and Asp112-Pro114. This speculate is able to locate B cell epitopes, which could help to find specific antigen and further benefit development of subunit vaccine.

\section{Acknowledgements}

This work was supported by grant from Program for Changjiang Scholars and Innovative Research Teamin in University (PCSIRT) (Grant no. IRT0848 ); Science and Technology project of Sichuan Province (No.08ZA082). Kaiyu Wang is the corresponding author. Fish Disease Research Center \& Key Laboratory of Animal Disease and Human Health of Sichuan Province, College of Veterinary Medicine of Sichuan Agricultural University, 46\# Xinkang Road, Yucheng District, Yaan
625014, Sichuan Province of China.

\section{REFERENCES}

[1] S.J.Schrag, D.Phil, E.R.Zell, M.Stat, R.Lynfield, A.Roome, K.E.Arnold, A.S.Craig, L.H.Harrison, A.Reingold, K.Stefonek, G.Smith, M.Gamble, A.Schuchat, "A population-based comparison of strategies to prevent early-onset group B streptococcal disease in neonates,” N. Engl. J. Med. New York, vol.347, pp.233-239, July 2002.

[2] M.S.Edwards, C.J.Baker, "Group B streptococcal infections in elderly adults,” Clin. Infect. Dis. New York, vol.41 pp.839-847, May 2005.

[3] T.H.Skoff, M.M.Farley, S.Petit, A.S.Craig, W.Schaffner, K.Gershman, L.H.Harrison, R.Lynfield, J.M.Boetani, S.Zansky, B.A.Albanese, K.Stefonek, E.R.Zell, D.Jackson, T.Thompson, S.J.Schrag, "Increasing burden of invasive group B streptococcal disease in nonpregnant adults 1990-2007,’Clin. Infect. Dis. New York,vol.49 pp.85-92, February 2009.

[4] G.P.Keefe, "Streptococcus agalactiae mastitis: a review," Can.Vet.J. Canada,vol.38, pp.429-437,July 1997.

[5] J.J.Evans, P.H.Klesius, P.M.Gilbert, C.A.Shoemaker, M.A.A.Sarawi, J.Landsberg, R.Duremdez, "Characterization of $\beta$-haemolytic group B streptococcus agalactiae in cultured seabream, Sparus auratus L., and wild mullet, Liza klunzingeri (Day), in Kuwait," J.Fish. Dis.Wiley, New York, vol.25, pp.505-513, September 2002.

[6] R.Salvador, E.E.Muller, J.C.Freitas, J.H.Leonhadt, "Isolation and characterization of Streptococcus spp. group B in Nile tilapia (Oreochromis niloticus) reared in hapas nets and earth nurseries in the northern region of Parana State,Brazil,” Ciência Rural Santa Maria, vol.35,pp.1374-1378, November 2005.

[7] A.Eldar, Y.Bejerano, H.Bercovier, "Streptococcus shiloi and Streptococcus difficile: two new streptococcal species causing a meningoencephalitis in fish," Curr.Microbiol.New York, vol.28, pp.139-143, March 1994.

[8] E.R.Moxon, J.S.Kroll, "The role of bacterial polysaccharide capsules as virulence factors,” Curr.Top.Microbiol. Immunol.Berlin, vol.150, pp.65-85, May 1990.

[9] A.S.Cross, "The biologic significance of bacterial encapsulation, ” Curr.Top. Microbiol. Immunol. Berlin, vol.150, pp.87-95, May 1990.

[10] D.O.Chaffin, S.B.Beres, H.H.Yim, C.E.Rubens, "The serotype of type Ia and III group B streptococci is determined by the polymerase gene within the polycistronic capsule operon,” J.Bacteriol.Washington DC, vol.182, pp.4466-4477, May 2000.

[11] E.Persson, S.Berg, B.Trollfors, P.Larsson, E.Ek, E.Backhaus, B.E.B.Claesson, L.Jonsson, G.Radberg, T.Ripa, S.Johansson, "Serotypes and clinical manifestations of invasive group B streptococcal infections in western Sweden 1998-2001,” Clin.Microbiol.Infect.Wiley, New York, vol.10, pp.791-796, September 2004.

[12] H.C.Slotved, F.Kong, L.Lambertsen, S.Sauer, G.L.Gilbert, "Serotype IX, a proposed new Streptococcus agalactiae serotype,” J. Clin. Microbiol. Washington DC, vol.45, pp.2929-2936, September 2007.

[13] M.E.Hickman, M.A.Rench, P.Ferrieri, C.J.Baker, "Changing epidemiology of group B streptococcal colonization,” Pediatrics. American Academy of Pediatrics, New York, vol.104, pp.203-209, August 1999.

[14] M.Waqner, T.Murai, B.Waqner, E.Gunther, J.Jelinkova, "JM9 strains, a new type of group B streptococci from Japan,” Zentralbl.Bakteriol. Elsevier, Amsterdam, vol.280, pp.488-496, March 1994. 
[15] N.Suanyuk, F.Kong, D.Ko, G.L.Gilbert, K.Supamattaya, “Occurrence of rare genotypes of Streptococcus agalactiae in cultured red tilapia Oreochromis sp. and Nile tilapia O. niloticus in Thailand-Relationship to human isolates?, "Aquaculture, Elsevier, Amsterdam, vol.284, pp.35-40, July 2008.

[16] P.Vandamme, L.A.Devriese, B.Pot, K.Kersters, P.Melin, "Streptococcus difficile is a nonhemolytic group $\mathrm{B}$, type $\mathrm{Ib}$ Streptococcus," IJSEM. Society for General Microbiology, London, vol.47, pp.81-85, January 1997.

[17] F.Stingele, J.R.Neeser, B.Mollet, "Identification and characterization of the eps (Exopolysaccharide) gene cluster from Streptococcus thermophilus Sfi6," J.Bacteriol. Washington DC, vol.178, pp.1680-1690, March 1996.

[18] S.Yamamoto, K.Miyake, Y.Koike, M.Watanabe, Y.Machida, M.Ohta, S.Iijima, "Molecular characterization of type-specific capsular polysaccharide biosynthesis genes of Streptococcus agalactiae type Ia, "J.Bacteriol. Washington DC, vol.181, pp.5176-5184, September 1999.

[19] A.Guidolin, J.K.Morona, R.Morona, D.Hansman, J.C.Paton, "Nucleotide sequence analysis of genes essential for capsular polysaccharide biosynthesis in Streptococcus pneumoniae type 19F,” Infect. Immun. Washington DC, vol.62, pp.5384-5396, December 1994.

[20] M.J.Cieslewicz, D.L.Kasper, Y.Wang, M.R.Wessels, "Functional analysis in type Ia group B Streptococcus of a cluster of genes involved in extracellular polysaccharide production by diverse species of streptococci,” J. Biol. Chem. Washington DC, vol.276, pp.139-146, January 2001.

[21] J.K.Morona, J.C.Paton, D.C.Miller, R.Morona, “Tyrosine phosphorylation of CpsD negatively regulates capsular polysaccharide biosynthesis in Streptococcus pneumoniae," Mol. Microbiol.Wiley, New York, vol.35, pp.1431-1442, March 2000.
[22] C.E.Rubens, L.M.Heggen, R.F.Haft, M.R.Wessels, "Identification of cpsD,a gene essential for type III capsule expression in group B streptococci,” Mol. Microbiol. Wiley, New York, vol.8, pp.843-855, May 1993.

[23] A. M. Baya, B. Lupiani, F. M. Hetrick, B. S. Roberson, R. Lukacovic, E. May, C. Poukish, "Association of Streptococcus sp. with fish mortalities in the Chesapeake Bay and its tributaries," J.Fish.Dis.Wiley,New York, vol.13, pp.251-253, May 1990.

[24] R.Duremdez, A. A.Marzouk, J. A. Qasem, A. A.Harbi, H. Gharabally, "Isolation of Streptococcus agalactiae from cultured silver pomfret, Pampus argenteus (Euphrasen), in Kuwait," J.Fish.Dis.Wiley,New York, vol.27, pp.307-310, May 2004.

[25] N.Suanyuk, H.Kanghear, R. Khongpradit, K.Supamattaya, "Streptococcus agalactiae infection in tilapia (Oreochromis niloticus),” J. Sci. Technol. Aquat .Sci. Songkhla, vol.27, pp.307-319, 2005.

[26] M. Imperi, M. Pataracchia, G. Alfarone, L. Baldassarri, G. Orefici, R. Creti, "A multiplex PCR assay for the direct identification of the capsular type (Ia to IX) of Streptococcus agalactiae," J. Microbiol. Methods, Elsevier, Amsterdam, vol.80, pp.212-214, December 2009.

[27] D. O. Chaffin, L. M. Mentele, C.E. Rubens, "Sialylation of group B streptococcal capsular polysaccharide is mediated by cpsK and is required for optimal capsule polymerization and expression,” J.Bacteriol. Washington DC, vol.187, pp.4615-4626, July 2005.

[28] A. L. Larentis, A. P. C. Argondizzo, G. dos S. Esteves, El. Jessouron, R. Galler, M. A.Medeiros, "Cloning and optimization of induction conditions for mature PsaA (pneumococcal surface adhesin A) expression in Escherichia coli and recombinant protein stability during long-term storage,” Protein Expr.Purif. Elsevier, Amsterdam, vol.78, pp.38-47, July 2011. 